$\mathrm{Oz}$

Volume 4

Article 21

$1-1-1982$

\title{
A Theatre: Jekyll Island, Georgia
}

Dixie Roberts Junk

Follow this and additional works at: https://newprairiepress.org/oz

(c) $($ ) $\Theta \Theta$

This work is licensed under a Creative Commons Attribution-Noncommercial-No Derivative Works 4.0 License.

\section{Recommended Citation}

Junk, Dixie Roberts (1982) "A Theatre: Jekyll Island, Georgia," Oz: Vol. 4. https://doi.org/10.4148/

2378-5853.1052

This Article is brought to you for free and open access by New Prairie Press. It has been accepted for inclusion in Oz by an authorized administrator of New Prairie Press. For more information, please contact cads@k-state.edu. 


\section{A Theatre}

\section{Jekyll Island, Georgia}

Dixie Roberts Junk

Critics: Gene Ernst Ed DeVilbiss

Richard Longstreth

Frank Locker

\section{Background}

Jekyll Island lies just off the coast of Georgia near Brunswick. The island has a rich history marked by several colorful eras, the most significant among them being the early 20th century, when it served as an exclusive winter resort for some of the nation's leading businessmen. Seeking to form a secluded retreat, these men formed the Jekyll Island Club. Soon afterwards, a clubhouse was constructed as the center for dining and social activities. With the addition of stores, a chapel, and casino, the resort grew into a small village. A few club members built cottages, employing architects such as John Galen Howard and McKim, Mead and White. In spite of these additions, the clubhouse remained the social and physical center of the compound.

In recent years, this enclave has become a National Historic Landmark. Several cottages have been renovated to accommodate a variety of uses including an art gallery and offices. The clubhouse is being restored as a hotel and restaurant. Proud of the island's history and its recent improvements, citizens have expressed a growing interest in a theatre for their summer repertory group. It is hoped that this addition, along with the preservation of existing buildings, will both improve the physical setting and give new vitality to the compound.

The program calls for a 500-seat theatre with administrative, produc70 tion, and performers' spaces, in ad-

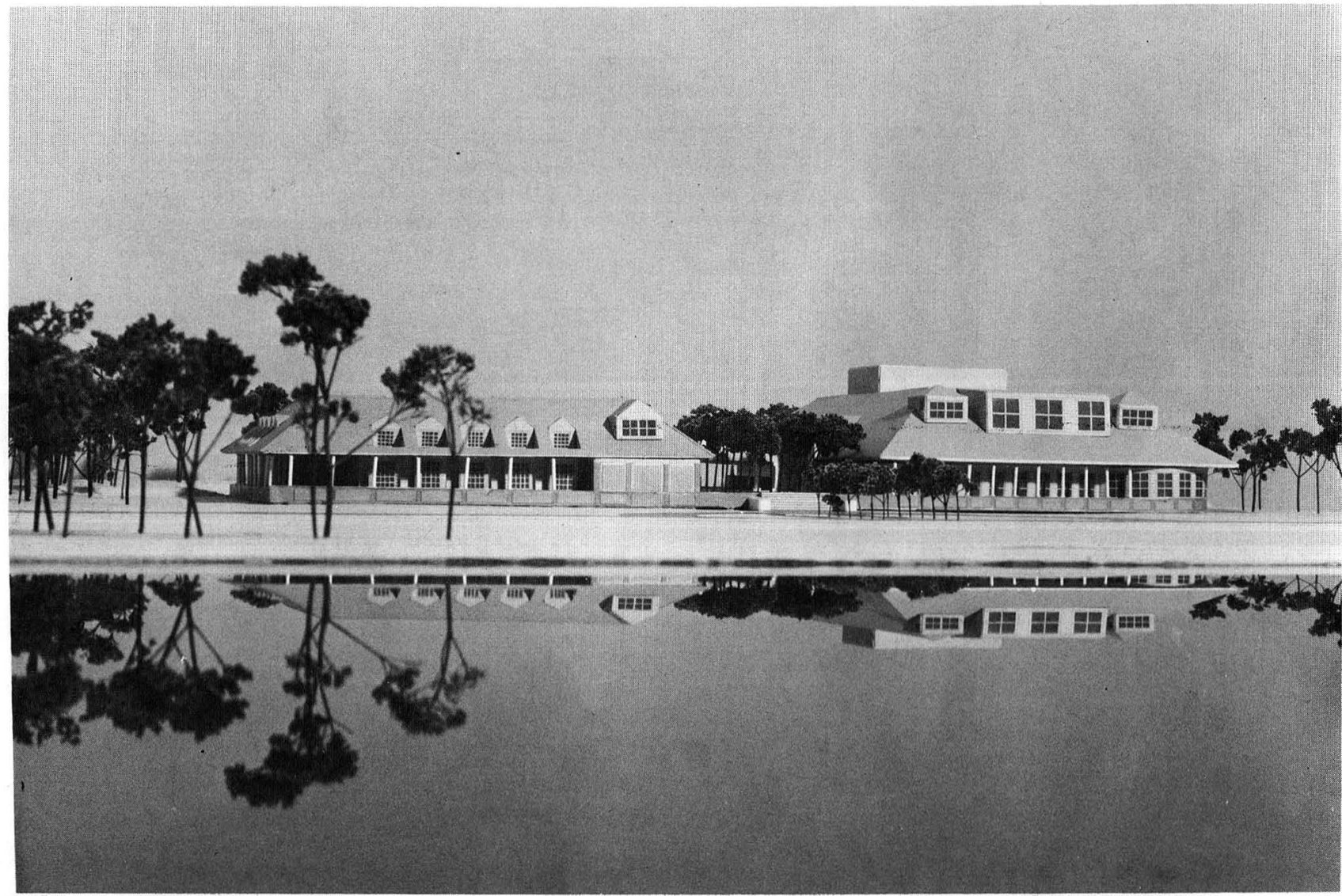

Southwest view

dition to housing for the actors.

\section{Solution}

The site lies on Riverview Drive, the main road within the compound, onto which fronts the larger cottages and the clubhouse. Each of these buildings possesses an individual character, drawing from a variety of picturesque and classical modes. But, due to common site and climatic conditions, the ensemble is harmonious rather than discordant.
The theatre attempts to address both these factors in its design.

A primary concern in the scheme was how to place a relatively large building in a residential area. The theatre is aligned with the cottages, and its apparent mass is diminished by the division of public and private zones. Trees in the entry court emphasize the division and allow each side of the building to read as an independent unit. The sloping roofs conceal the large volume of space required to accommodate stage and auditorium requirements and evoke both residential and regional images.

The building organization evolves from a strong relationship between centralized interior and exterior spaces. The public side consists of the stage and lobby spaces with the auditorium volume serving as a central courtyard. The apartment units 


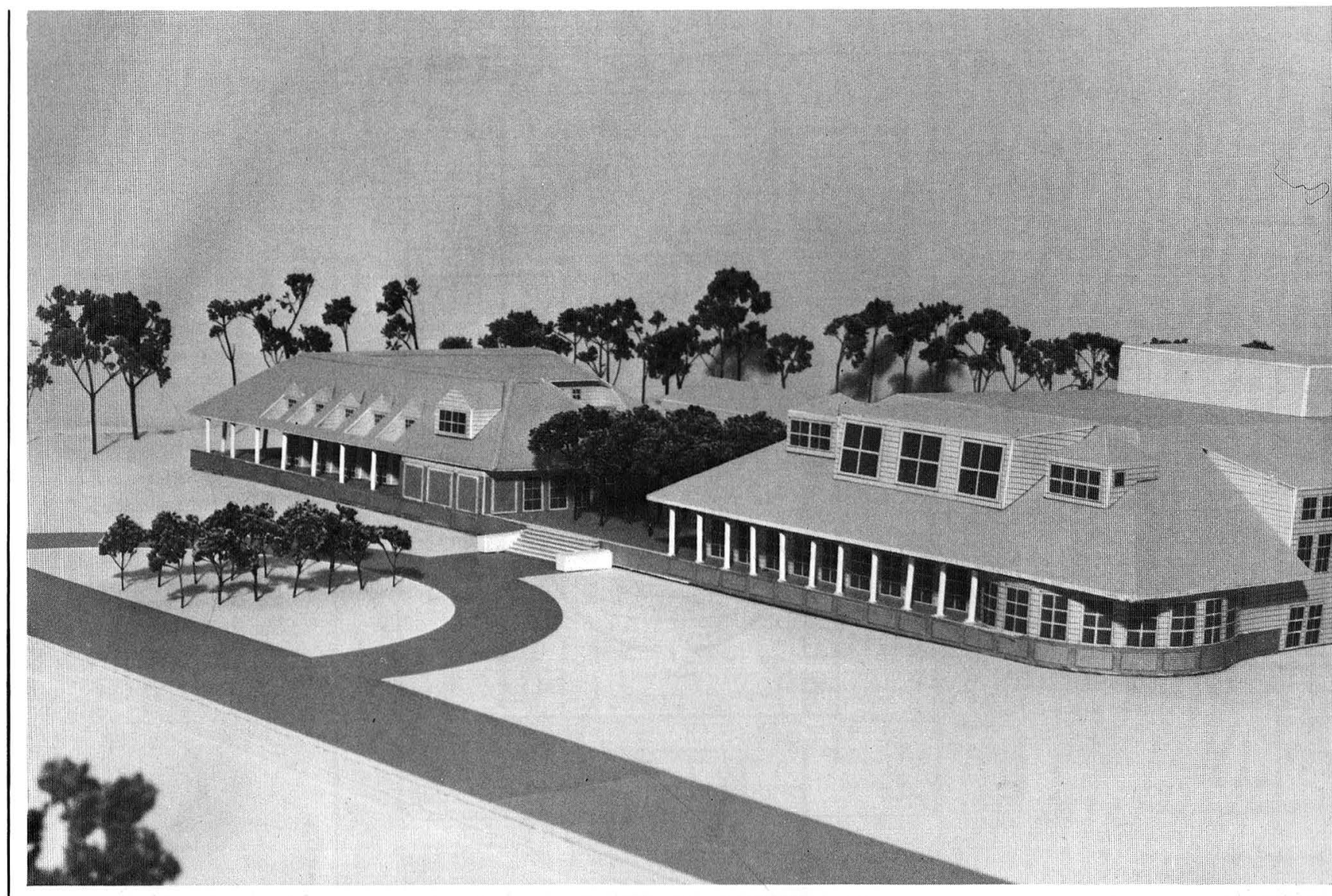

surround a community garden which becomes a negative volume juxtaposed against the positive volume of the auditorium. The outdoor entry court resolves the axial relationship between these volumes and mediates public and private zones.

The placement of the building on the site establishes a hierarchy of order between the primary plane of the clubhouse, the physical and symbolic center of the enclave, and the secondary plane of cottages. To preserve the significance of the clubhouse, the theatre lies on this secondary plane and assumes a subordinate role. The facade and entry court make a gesture to the river, acknowledging its importance and historic value as the original means of arrival to the island. Porches and verandas frame the river vista while dormers provide a more intimate and focused view from inside. Two types of dormers distinguish the public and private sides. The residential dormers are inverted, smaller in scale, and reflect individual spaces; the dormers on the public side project outward and serve group spaces. In addition, these elements serve to break up the mass of the building and reinforce its residential character. The solution also recalls the raised floors of the surrounding cottages. Functionally, it provides both a crawl space for ventilation and protection from high water; symbolically it emphasizes the character of the site and creates a ceremonial stepped entry.

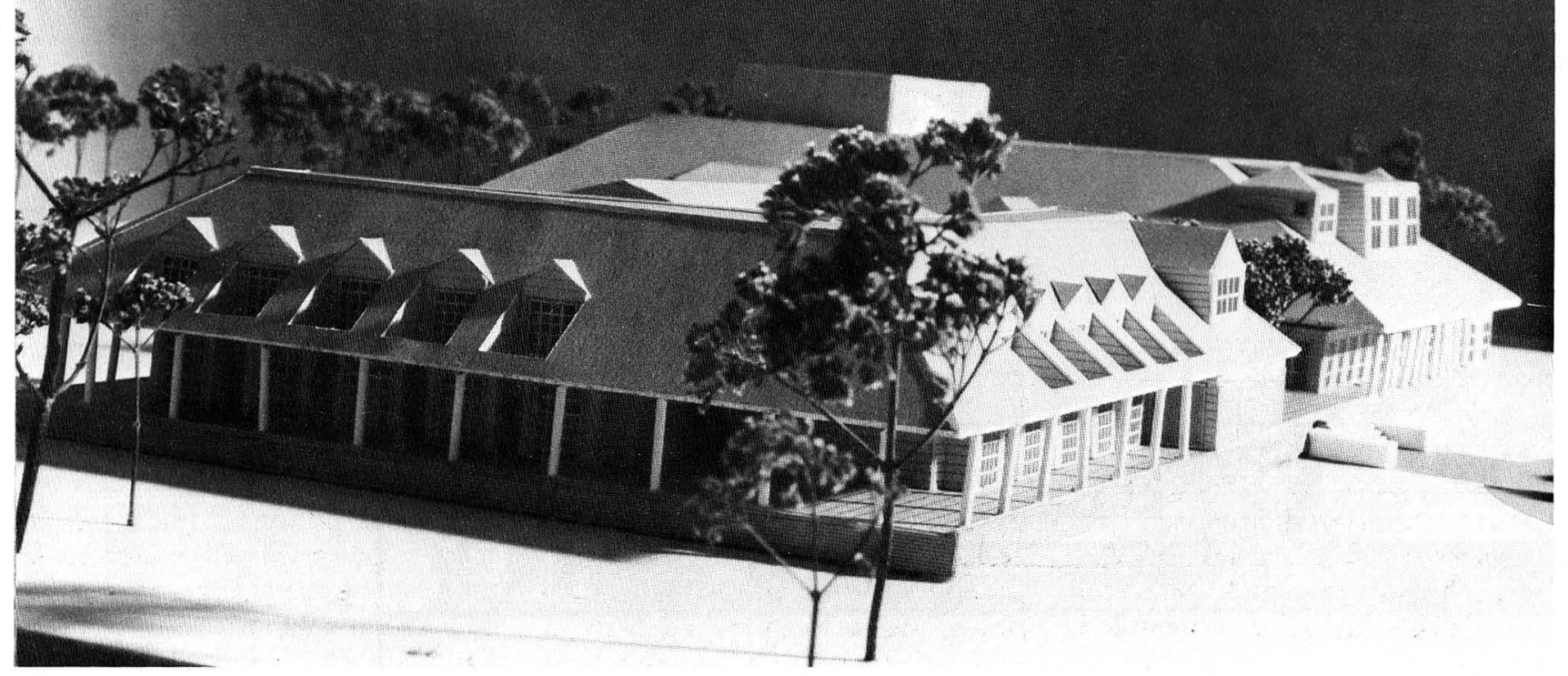

View from south

View from north 


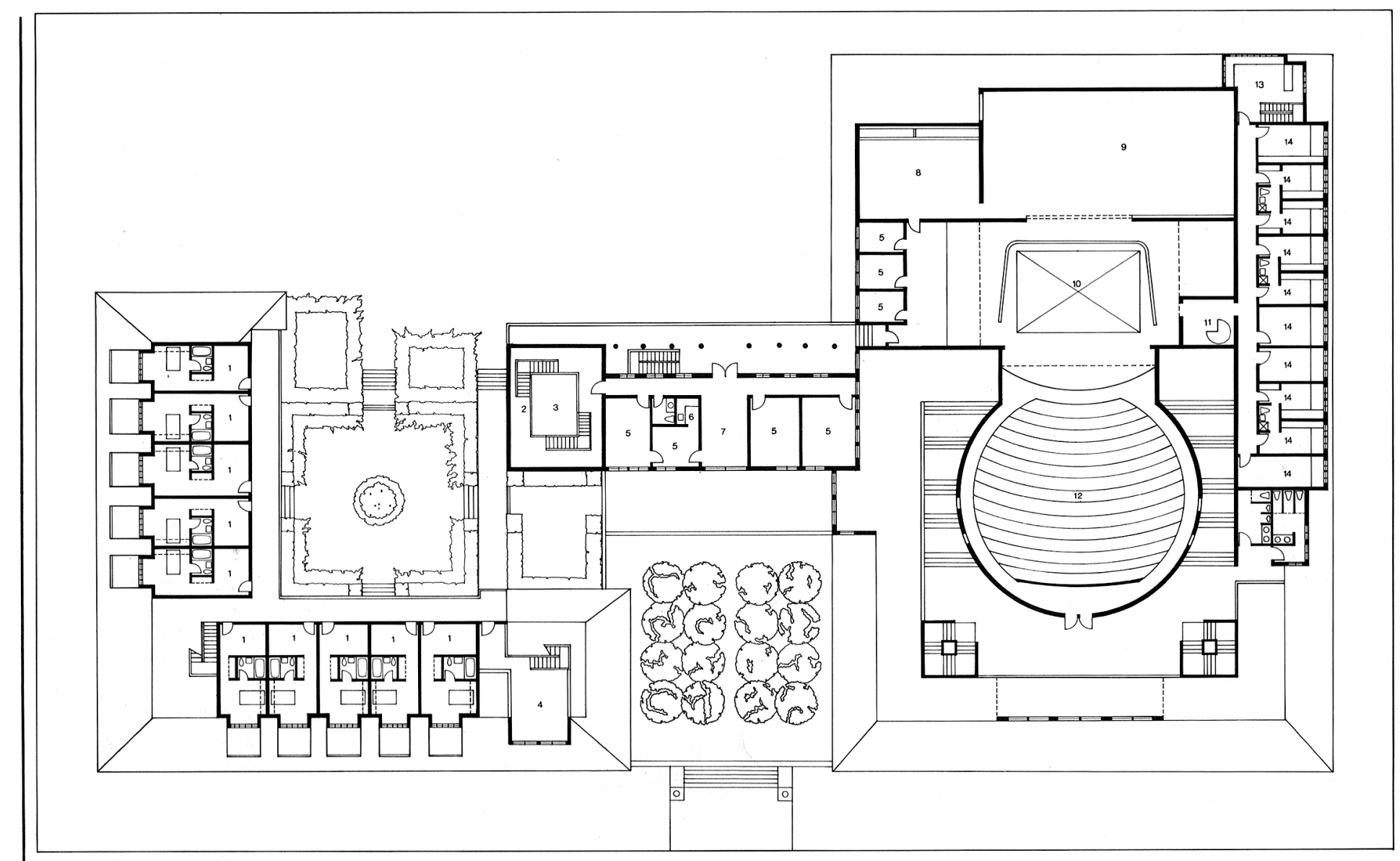

STAGE LEVEL PLAN

1. Apartments

2. Library

3. Open

4. Loft

5. Offices

6. Work Room

7. Receptionist

8. Paint Shop

9. Scenery Shop

10. Stage

11. Ante-room

12. Auditorium

14. Dressing Rooms

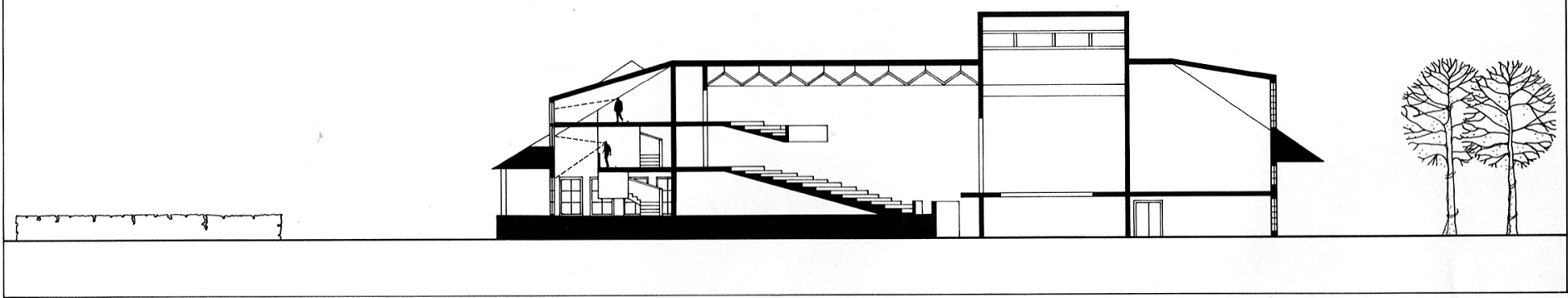

Section thru theatre
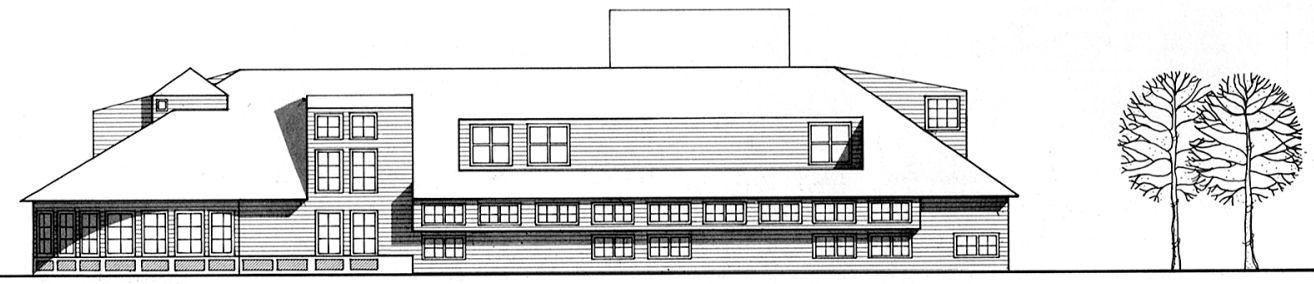
TERRACE LEVEL PLAN

1. Apartments

2. Library

4. Community Living/Dining

5. Outdoor Bar

6. Mechanical

7. Rehearsal Room

8. Storage

9. Trap

10. Box Office

11. Orchestra Pit

12. Lower Auditorium

13. Lounge

14. Chorus Dressing Rooms

15. Changing Rooms
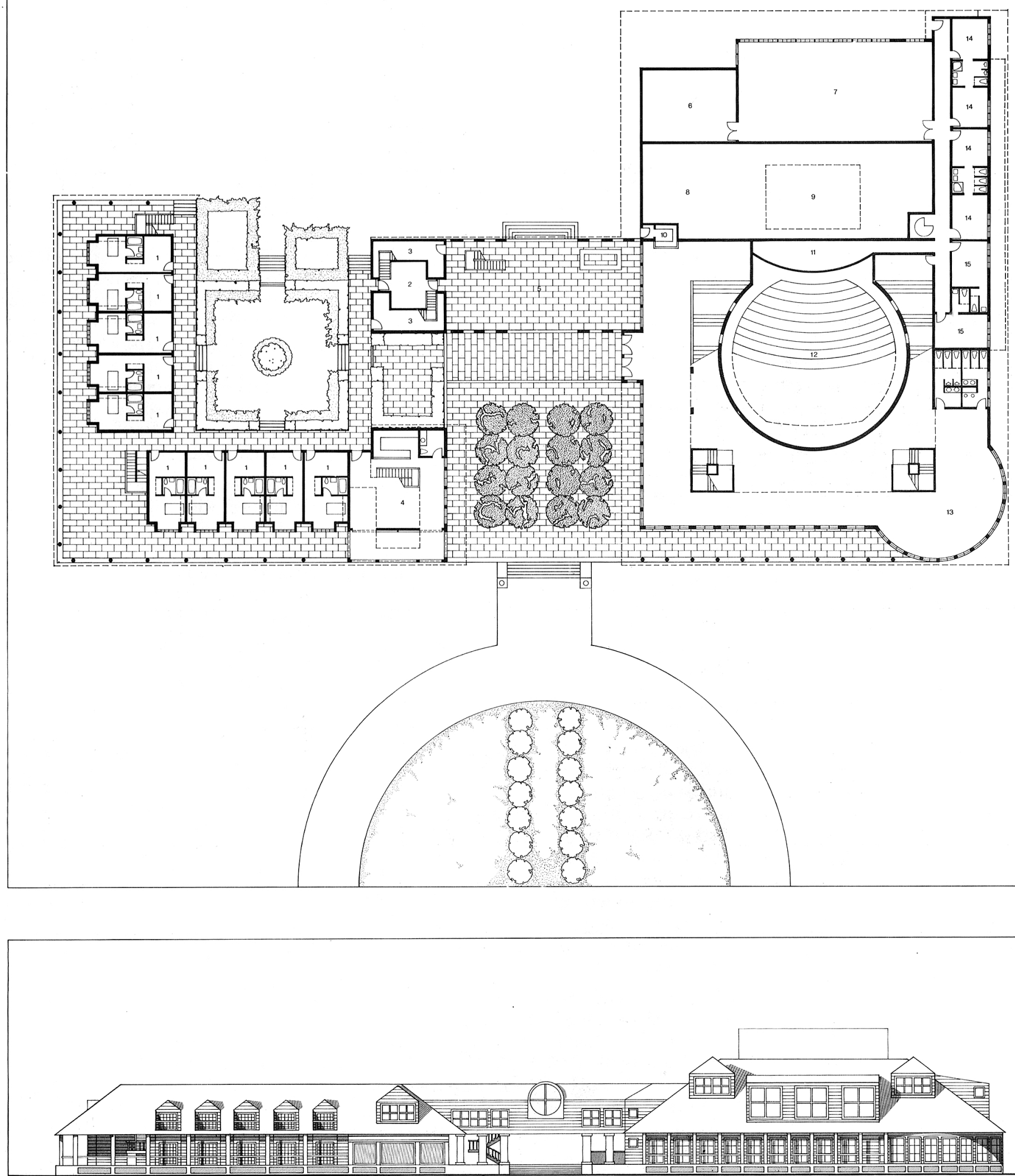

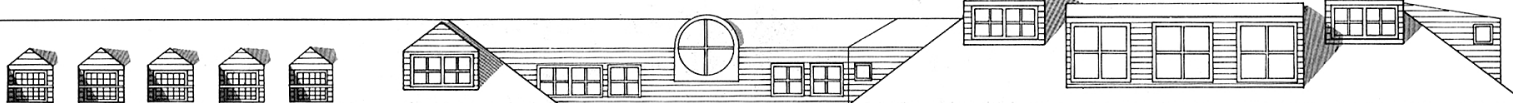

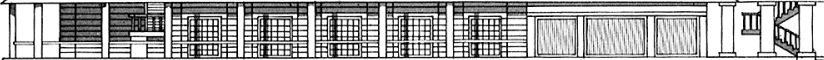

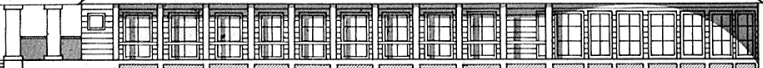

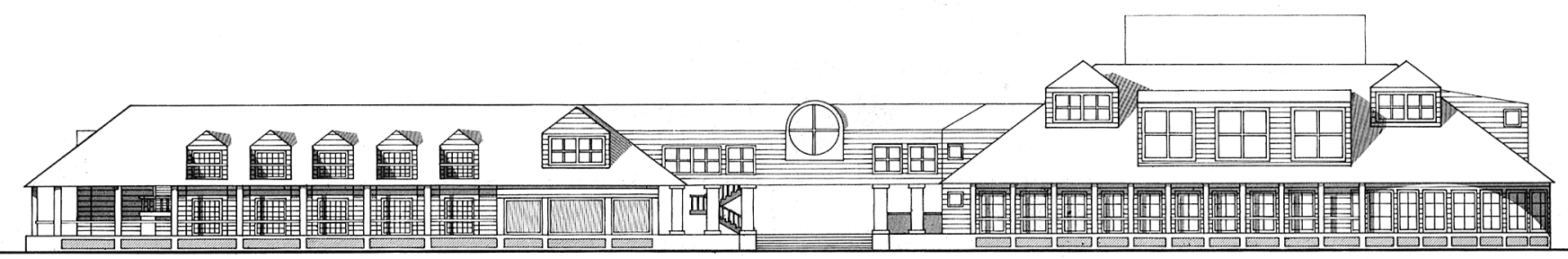

